\title{
Predation risk on incubating adults constrains the choice of thermally favourable nest sites in a plover
}

\author{
JUAN A. AMAT* \& JOSÉ A. MASERO† \\ *Estación Biológica de Doñana, Consejo Superior de Investigaciones Científicas \\ yDepartamento de Biología Animal, Universidad de Cádiz
}

(

\begin{abstract}
Birds are thought to choose nest sites that meet two main functions: providing security to both nest contents and incubating adults, and providing an appropriate microclimate for incubation. Many shorebirds nest in sites with no or little cover. In a lake in southern Spain, nearly $70 \%$ of the nests of Kentish plovers, Charadrius alexandrinus, were in sites with little or no cover, where ambient temperatures might be more than 50(C during very hot days, thus causing the incubating adults to suffer from heat stress. We tested the hypothesis that Kentish plovers nest mainly in exposed sites because this may allow the incubating birds to detect approaching predators early, and thus to reduce predation risk. When we occluded the view that incubating adults had from their nests, they took longer to detect approaching predators than when the view was unrestricted. Incubating adults were also more frequently killed by mammals in covered than in exposed nests. Females that nested in covered sites were in lower body condition than those nesting in exposed sites, possibly because they were unable to withstand the high ambient temperatures in exposed sites. Thus, the benefits of thermally favourable nest sites are reduced by the constraints of predation risk.
\end{abstract}

The effects of predation may have a considerable impact on the life history strategies of animals, and in particular on the choices of foraging and nest sites (Lima 1990; Martin 1993). Animals can assess and modify their risk of predation by seeking sites where this risk is lower (Lima \& Dill 1990). Predation is the main cause of avian nest failure (Skutch 1949; Ricklefs 1969), and may also represent an important source of adult mortality at nests (Sargeant et al. 1984). Even if the risk of predation on adults attending nests is small, its consequences for the breeding strategies of birds are not negligible (Curio \& Regelmann 1986; Lima \& Dill 1990; Lima 1993), given the importance of life span on lifetime reproductive success (Thomas \& Coulson 1988; Martin 1993). Therefore, natural selection should favour individuals that choose nest sites that minimize the risk of predation, on both nest contents and incubating adults.

In addition to providing security, another important function of nest sites is to provide an appropriate microclimate for incubation. For birds, high environmental

Correspondence: J. A. Amat, Estación Biológica de Doñana, C.S.I.C., Apartado 1056, E-41080 Sevilla, Spain (email: aguilar@cica.es). J. A. Masero is at Departamento de Biología Animal, Facultad de Ciencias del Mar, Universidad de Cádiz, Apartado 40, E-11510 Puerto Real, Spain. temperatures may impose a need to conserve water, especially in arid environments. One way in which birds may reduce thermoregulatory costs is to seek thermally favourable sites, which may be achieved simply by shifting between microsites that may be separated by only a few centimetres (Thomas \& Maclean 1981; Wolf \& Walsberg 1996). However, this strategy is not usually possible for birds incubating under direct solar radiation, since if the incubating bird moves to a thermally more favourable place, the eggs would remain uncovered and could reach lethal temperatures in only a few minutes, unless they are moved as well (Grant 1982). Many shorebird species nest in sites with little or no cover. Temperatures at ground level in this type of site may exceed 50(C during the hottest parts of the day, and the incubating birds may thus incur heat stress (Purdue 1976; Grant 1982; Ward 1990).

Given that covered sites, where incubation would not be so heat stressful, may be readily available, it seems paradoxical that shorebirds do not use them more frequently. It has been suggested that many shorebirds nest in exposed sites to facilitate early detection of predators (Grant 1982; Maclean 1984; Burger 1987; Ward 1990; Lauro \& Nol 1995). Most adult shorebirds do not use cover to escape from predators, but take flight instead. Objects that obstruct vision may hamper predator detection close 
to the nest, allowing the incubating adult to be caught by surprise. For shorebirds, it therefore seems important to detect predators early, which is greatly facilitated by an unrestricted view (Metcalfe 1984; Lima 1992; Gö tmark et al. 1995; Koivula \& Rönkä 1998).

Weidinger (2002) showed that there are complex interactions between factors influencing nest predation, within as well as between species. Indeed, within shorebird populations there is a remarkable diversity in the use of cover of nest sites (e.g. Fraga \& Amat 1996). What this may tell us is that the benefits and costs of nesting in different situations may not be similar for all individuals. Thus, some individuals would expose themselves to more risky situations than others. According to the theory of state-dependent life histories, shorebirds of different physiological states should adopt different nesting tactics (McNamara \& Houston 1996). For instance, if nesting in exposed sites imposes a physiological cost on incubating birds, body condition could affect the use of exposed sites, which are not protected from direct solar radiation and in which thermoregulatory costs may be higher. Wiebe \& Martin (1998) showed that white-tailed ptarmigan, Lagopus leucura, females in poorer body condition more frequently used covered sites, where predation on incubating birds was higher, than females in better condition.

In consequence, conflict between demands for escape from predators and thermoregulation may occur if incubating shorebirds are more vulnerable to predators when they nest in thermally favourable sites. A solution to this trade-off is to choose sites where the adults can quickly detect approaching predators, even though they make the nest contents more vulnerable to predators (Marzluff 1988; Götmark et al. 1995; Wiebe \& Martin 1998; Whittingham et al. 2002). Seasonal differences in ptarmigan nest sites led Wiebe \& Martin (1998) to conclude that microclimate should be more important than predation pressure in determining the choice of site. However, some shorebirds nesting in hot environments do not show seasonal variations in the characteristics of nest sites (Fraga \& Amat 1996), despite facing heat stress throughout the nesting season, suggesting that predation pressure should be more important in this case in determining the choice of nest site. This may indicate that the resolution of this type of trade-off may depend on species identity or environmental conditions.

Wiebe \& Martin (1998) based their conclusions on observational data. We used observational and experimental data to investigate how incubating Kentish plovers, Charadrius alexandrinus, cope with predation risk. This species readily nests on exposed sites, even in hot environments (Grant 1982; Page et al. 1985; Warriner et al. 1986; Fraga \& Amat 1996). We analysed (1) whether predation on incubating adults was more frequent at more concealed sites, as well as the responses of incubating birds to predators; (2) whether males were more vulnerable than females to predators, since males perform most nocturnal incubation (Nakazawa 1979; Fraga \& Amat 1996; Kosztolá nyi \& Székely 2002), and in these conditions the detectability of predators may be lower because of reduced visibility; and (3) whether the choice of nest sites was dependent on the body condition of incubating adults. Kentish plovers are sequentially polygamous (Page et al. 1985; Warriner et al. 1986; Fraga \& Amat 1996). If there is sex-related mortality of incubating adults, the operational sex ratio, and hence the opportunities for polygamous matings, could be affected as well.

\section{METHODS}

\section{Study Site}

Our study was conducted at Fuente de Piedra lake (1354 ha), in Málaga province, southern Spain (37(06\#N, 4(45\#W), during MarcheJuly 1991e1999. Artificial dykes and islets were constructed at the lake during the 20th century, when the salt was commercially exploited (Rendón-Martos \& Johnson 1996). Kentish plovers nest on these dykes or islets (both termed hereafter 'islands') and on the lake shore. The water level in the lake varies both within and between breeding seasons, and when very low, island sites are accessible to terrestrial predators. The lake remained dry during most of the breeding season of 1995, but flooded in 1991 and 1996e1999, whereas in 1992e1994 it dried up before the breeding seasons had finished. Because of exceptionally high water levels (O1.65 m), the islands were covered with water in 1997 and 1998.

In this lake, Arthrocnemum glaucum is the main plant species used as nesting cover by Kentish plovers (Fraga \& Amat 1996). This plant is abundant on the lake; it covers all islands and forms a belt 10 e200 $\mathrm{m}$ wide around the lake.

\section{Nesting Biology}

Once a nest was found, it was individually marked, and the same observer (J.A.A.) recorded its degree of cover, according to four categories: 0 when the nest was completely exposed, and $1 \mathbf{e} 3$ when the nest was $075 \%$, $25 \mathbf{e} 75 \%$ or $! 25 \%$ exposed. J.A.A. walked 360 ( around the nest and estimated the percentage of circumference length (radius approximately $1 \mathrm{~m}$, centred at the nest) from which the nest was visible, i.e. not occluded by cover. As an indicator of possible heat stress, we measured solar irradiance on the horizontal plane at the centre of nest scrapes and also at a completely exposed site about $1 \mathrm{~m}$ from the nest site, by using a LI-COR pyranometer sensor LI-2000SZ (LI-COR, Lincoln, Nebraska, U.S.A.). The measurements were taken on 2 consecutive days with clear skies, between 0800 and 1200 hours GMT, once the nesting season of 1991 had finished. Solar irradiance at each nest site was expressed as the percentage of the irradiance recorded at the site relative to that recorded at a corresponding exposed site nearby.

Adults were captured at nests using walk-in traps, and were individually marked with a metal ring and a combination of three colour rings. We weighed them, with a Pesola spring balance (to the nearest gram), and, using vernier callipers and a rule, we also measured bill (culmen) and tarsus lengths (to the nearest $0.1 \mathrm{~mm}$ ) and wing length (to the nearest millimetre). 


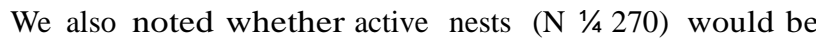
accessible to mammalian predators. A nest was considered active from the date of laying of the first egg until the nest was no longer attended by adults. All nests on the shore were accessible to mammals, but nests on islands were accessible to mammals, as evidenced by the presence of footprints, only when water covered less than $40 \%$ of the lake's surface, because under such circumstances most islands remained in contact with the lake shore. We revisited nests every $3 \mathbf{e} 6$ days to determine their fate. Evidence of hatching included subsequent observation of colour-marked adults with chicks, or the presence of chicks or small pieces of detached eggshell membranes in the nest. Evidence of predation included yolk or partially eaten eggs in the nests, or the disappearance of eggs before expected hatching. Nests were considered deserted when eggs were cold on subsequent visits and successful when at least one egg hatched. To disentangle the effects of mammals on nesting success, we estimated survival times of nests according to whether the nest sites were accessible to terrestrial predators while the nests were active.

If the laying date of a nest was unknown, we estimated the number of days that the nest had been active, using an equation that took into account the rate of daily mass loss of eggs during incubation in relation to egg volume (for details see Fraga \& Amat 1996; Amat et al. 1999b). For unsuccessful nests, we assumed failure to have occurred midway between the last visit on which the nest was active and the following visit. There were no differences in the rates at which nests in different habitat types were visited.

We also recorded all cases of predation on incubating adults. We witnessed only two cases of predation, both on birds that left their nests to perform distraction displays to predators. In the remaining cases we did not see predation events, but identified adults killed by predators by the colour and metal rings. The species of predator could rarely be identified, but was inferred in some cases from footprints recorded within $10 \mathrm{~m}$ of the nests.

\section{Responses to Predators}

To determine the behaviour of incubating adults, during 1997 e1999 we set up blinds 15 e20 m from 42 nests, and recorded the responses of the plovers to potential predators, including dogs, as well as birds flying within $50 \mathrm{~m}$ of the nests, such as raptors (kestrel, Falco tinnunculus, peregrine falcon, F. peregrinus, black kite, Milvus migrans, booted eagle, Hieraaetus pennatus, Montagu's harrier, Circus pygargus, and marsh harrier, C. aeruginosus), gull-billed terns, Gelochelidon nilotica, shrikes (great grey shrike, Lanius excubitor, and woodchat shrike, L. senator) and ravens, Corvus corax. The terns and woodchat shrikes do not prey on adults, although at Fuente de Piedra the terns are the main avian nest predators (Fraga \& Amat 1996). We allocated the responses to predators to the following categories (for definitions see Cairns 1982; Zharikov \& Bondrup-Nielsen 1996): (1) aerial pursuit of avian predators, (2) 'tail-up' display to aerial predators, (3) no reaction, (4) crouch tightly on the nest, (5) run away, and (6) fly away. At Fuente de Piedra, distraction displays were infrequent when we approached the plover nests and were never observed from blinds. The continuous observation periods from blinds lasted a mean G SD of 225:6 G 56:80 min=nest ( $\left.N^{1 / 4} 42\right)$.

During 1998e1999 we performed an experiment to determine whether the ability of incubating plovers to detect approaching predators was affected by the degree of nest concealment. For this experiment, we chose nests that had been incubated for more than 5 days. We did not find effects of stage of incubation on the responses of plovers (data not presented), except for a few hours before hatching, so we did not include nests on the last day of incubation. We covered 11 Kentish plover nests that initially had no cover with twigs of Arthrocnemum bushes, so that these nests resembled nests with the highest degree of cover (category 3). Cover was manipulated from a few hours before observations started until observations at each nest finished, which usually took less than $10 \mathrm{~h}$. A control group of 10 completely exposed nests was not covered with vegetation. Treatments were randomly assigned to nests. The off-duty parent does not always remain in the nesting area, but may move to forage elsewhere when relieved by its partner. To keep conditions constant, and avoid situations where the off-duty parent might prevent predators from approaching, we captured the males of the two groups of nests about $5 \mathrm{~h}$ before starting observations, and kept them in captivity (approximately $8 \mathbf{e} 10 \mathrm{~h}$ ) until we finished observations at their nest. Males were captured at sunrise, as incubation shifts between pair members usually occur at that time. Because females incubate during daylight (Fraga \& Amat 1996; Kosztolá nyi \& Székely 2002), nests were not left unattended. Captive males were maintained in individual cages ( 1 】 0:5 m and $0.8 \mathrm{~m}$ high), where food (a mixture of mealworms, fly larvae and pieces of hard-boiled hens' eggs) and water were provided ad libitum. Observations of the responses of the incubating plovers in these two groups of nests were conducted from a blind, as described above, from 1000 to 1500 hours GMT.

We also performed another experiment during 1999 to collect data on flushing times of the incubating plovers according to the visibility that they had from their nests. Nests for this experiment were selected arbitrarily, and all had no cover and were on the lake shore. We did not remove one of the pair members in this experiment, because we recorded data arbitrarily according to time of day. To record flushing times when the visibility from the nests was obstructed, on one side of the nests we placed a row (50 cm long I $30 \mathrm{~cm} \mathrm{tall)} \mathrm{of} \mathrm{twigs} \mathrm{of} \mathrm{Arthrocnemum}$ bushes perpendicular to the lake shore and $15 \mathrm{~cm}$ from the nest scrape, ensuring that visibility was completely obstructed from the opposite side, from which we approached directly from $300 \mathrm{~m}$ by walking at constant speed, during both day (12 nests) and night (six nests). Even during the night, this was easily accomplished, as the zone of the lake shore where the plovers nested is narrow $(10 \mathbf{e} 15 \mathrm{~m})$ and the nests were easily found. Another group of completely exposed nests in which visibility was not manipulated served as a control, during both day (12 nests) and night (five nests). Treatments were randomly assigned to nests. 
Because the precise moment when the plovers departed from nests could not be determined visually at night, we estimated it from the difference in time from when the plover stopped incubation and we arrived at the nests. To record this time, $1 \mathbf{e} 2 \mathrm{~h}$ before flushing incubating birds, we substituted one of the eggs in the nests by a Kentish plover egg filled with plaster of Paris, into which a thin (36 gauge) coppereconstantan thermocouple had been inserted. The original eggs were placed in nearby nests. The thermal conductivity of plaster of Paris is identical to that of a natural egg (Ward 1990). The thermocouple was connected to an Omega OM-550 datalogger (Omega Engineering, Inc., Stamford, Connecticut, U.S.A.), which recorded temperatures every second. We stopped data recording by the datalogger immediately after we arrived at the nest site, and then returned the original eggs to their nests. (Hatching success was not affected.) We established flushing time by recording the time between a drop in egg temperature and the moment at which the datalogger was stopped.

To confirm that the moment the incubating bird left the nest matched a corresponding change in egg temperature, in 14 nests we placed an egg filled with plaster of Paris and connected the thermocouple to a datalogger. We set up a blind 15 e20 $\mathrm{m}$ from these nests, from which we waited until the incubating birds had been incubating for $10 \mathrm{~min}$, after which we flushed them. At the same moment that the birds left the nests, we started a stopwatch. We then approached the nests and stopped simultaneously both the datalogger and the stopwatch. This procedure confirmed that the time elapsing from the moment the egg temperature fell until our arrival at the nests provided a reliable estimate of flushing times, as there was an almost perfect correlation between the moment in which the incubating bird left the nest and we stopped the datalogger and the time recorded with the stopwatch (Pearson correlation: $r_{12}^{2} 1 / 40: 96, P$ I 0:001). However, if ambient temperature is high, the drop in egg temperature may not be accurately recorded. To avoid this, we recorded the data on flushing times when ambient temperature was below 23(C.

\section{Statistical Analyses}

In most analyses we considered only one nest per female. Only first nests were considered, that is, renesting attempts within a breeding season were excluded. When we had several nests per female during different years, the nest of the corresponding female included for the analyses was chosen at random. Sample sizes differ in some analyses because some nests were protected with enclosures for other purposes (Amat et al. 1999b), and we ignored these when calculating nesting success but included them in other analyses (e.g. choice of cover, body condition of incubating adults). Data were tested for normality before being analysed with parametric tests. If they were not normally distributed, they were transformed following Zar (1984), but nontransformed data are presented to facilitate interpretation.

To test the hypothesis that use of nesting cover is dependent on body condition, we chose individual plovers that changed nest cover category between years, and compared their condition in the different categories. Renesting attempts were not considered for this last type of comparison. To derive a measure of structural body size, we used the first principal component scores (PCI) from culmen, tarsus and wing lengths. These variables loaded positively on the first axis, which explained $45 \%$ of the variation in size. For an index of bird condition, we used the residuals of a regression of body masses on these PCI scores. We performed these calculations separately for males and females. Because we caught the plovers at different stages of incubation, changes in body mass during incubation would affect the reliability of the body condition index. Nevertheless, a study in Fuente de Piedra showed that there were no statistically significant changes in body mass for female or male Kentish plovers during incubation (Amat et al. 2000). We have no direct evidence that body condition during incubation is indicative of condition at the moment that females decide where to lay. However, we have no reason to suspect that this would be the case, as female shorebirds acquire nutrients for egg formation just before laying, and do not capitalize on stored reserves (Klaasen et al. 2001).

Statistical tests were conducted with SYSTAT (Wilkinson 1990). Unless otherwise indicated, mean values are presented G1 SD. Tests were two tailed.

\section{RESULTS}

\section{Nest Cover and Predation}

We found 360 Kentish plover nests, most of which were in sites with little or no cover (Fig. 1). The choice of covered sites was not limited by cover availability, since Arthrocnemum, the main plant used for nest cover, is abundant at the study site (Fraga \& Amat 1996). Predation was the main cause of nest failure (53.5\% of 256 nests). The time that nests remained active was not affected by their degree of exposure (ANOVA: $F_{3 ; 266} 1 / 4$ 1:89, P 1/4 0:132;

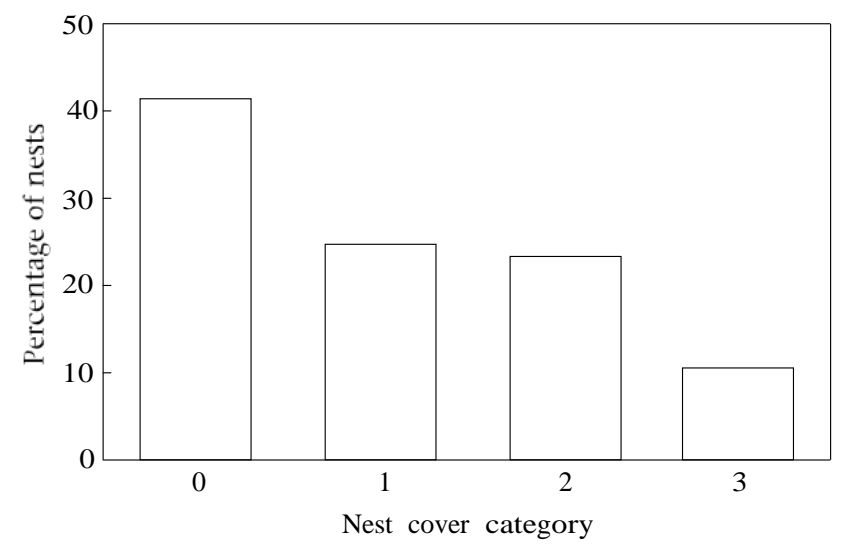

Figure 1. Frequency distribution of Kentish plover nests according to cover (NZ360). Nest cover was allocated to the following categories: 0 when the nest was completely exposed, and $1 \mathbf{e} 3$ when the nest was $\mathrm{O} 75 \%, 25 \mathbf{e} 75 \%$ or ! $25 \%$ exposed, respectively, from the sites $1 \mathrm{~m}$ around the nest. 


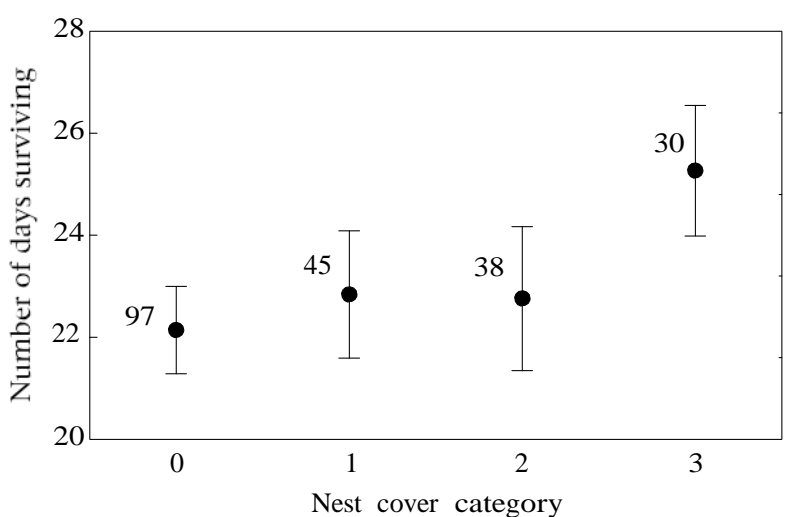

Figure 2. Mean number of days G1 SE that Kentish plover nests survived according to their degree of cover (as defined in Fig. 1). Survival times were considered as the number of days elapsing from laying of the first egg until the eggs hatched, or were predated or deserted. The average maximum number of days that nests may survive is 31 . Sample sizes are shown beside the points.

Fig. 2). Island nests not accessible to mammals survived longer (26:2G7:50 days, $N$ 1/4 52) than nests placed in accessible sites (22:3G8:58 days, N 1/4 218; Student's t test: $\mathrm{t}_{268} 1 / 42: 96, \mathrm{P} 1 / 4$ 0:003).

\section{Responses to Predators}

Incubating plovers reacted to $66 \%$ of gull-billed terns, $78 \%$ of raptors and to all other predators (Table 1). The degree of reaction also varied according to the type of predator. Thus, the plovers flew away more frequently when raptors approached the nests than when gull-billed terns did.

To analyse the effect of nest cover on the responses of plovers to predators, we considered only the responses to gull-billed terns, as this species was the predator that more frequently approached Kentish plover nests (Table 1). The frequency with which the plovers did not react may be an indication that an approaching tern had not been detected. We calculated the rates at which individual plovers did not react to passing flying terns near their nests as the proportion of times that plovers did not react relative to the total number of times that terns passed near focal nests. Incubating plovers failed to react significantly

Table 1. Frequency distributions (\%) of responses of incubating Kentish plovers when gull-billed terns, raptors or other potential predators approached their nests

\begin{tabular}{|lccc|}
\hline Response & $\begin{array}{c}\text { Terns } \\
\text { (NZ203) }\end{array}$ & $\begin{array}{c}\text { Raptors } \\
\text { (NZ18) }\end{array}$ & $\begin{array}{c}\text { Others* } \\
\text { (NZ8) }\end{array}$ \\
\hline No reaction & 34.5 & 22.2 & 0 \\
Aerial pursuit & 4.4 & 0 & 0 \\
Tail up & 1.0 & 0 & 0 \\
Crouch tightly & 11.8 & 5.6 & 0 \\
Run away & 44.8 & 44.4 & 50.0 \\
Fly away & 3.4 & 22.2 & 50.0 \\
\hline
\end{tabular}

Number of cases that predators approached nests are given in parentheses.

*Includes dogs, shrikes and common raven. more often in the experimentally covered nests (0:55G $0: 43, \quad \mathrm{~N} 1 / 411)$ than in the exposed nests (0:26G0:20, N 1/4 10; Student's t test: $t_{19} 1 / 42: 25$, P 1/4 0:036). Therefore, natural predators were apparently detected at longer distances from exposed than from concealed nests.

This was confirmed in the experiment in which we flushed incubating birds. Both degree of visibility from nests (ANOVA: $F_{1 ; 31} 1 / 4$ 48:63, P I 0:001) and time of day $\left(\mathrm{F}_{1: 31}\right.$ 1/4 29:98, $\mathrm{P}$ I 0:001) affected the flushing times, with plovers departing sooner from nests with an unrestricted view (day: 83:4G38:9 s, N 1/4 12; night: 20:4G13:2 s, N 1/4 5) than from nests with visibility occluded (day: 15:4G16:5 s, N 1/4 12; night: 4:0G5:3 s, N 1/46). Also, when an observer approached, the plovers left their nests sooner during daylight hours than at night. The visibility by time of day interaction was not significant $\left(F_{1 ; 31} 1 / 4\right.$ 0:06, P 1/4 0:810). No plover involved in this experiment performed distraction displays after leaving its nest.

\section{Predation on Incubating Plovers}

We found 23 adults preyed upon at 22 nests (1.95\% of all nests found during the study, including more than one nest per female, $N^{1 / 4} 1130$ ). A female and a male were preyed upon while performing distraction displays to a kestrel and two dogs, respectively. We saw a female Montagu's harrier eating a female Kentish plover about $2 \mathrm{~m}$ from her nest, and so she could have been caught while performing a distraction display. A male was captured on his nest by a red fox, Vulpes vulpes. Two females could have been killed by weasels, Mustela nivalis, and 11 males and both members of a pair were probably killed by polecats, Mustela putorius. Mammals also killed incubating plovers in four cases, which involved two females and two males, but we could not determine predator identity. To sum up, in all the instances in which predation occurred while the birds were incubating (i.e. not performing distraction displays), the predator was a mammal.

To analyse the effect of nest cover on predation risk of incubating plovers, we excluded those nests in which breeding plovers were killed while performing distraction displays to predators. Of the 19 nests in which incubating plovers were killed, one $\mathbf{( 5 . 2 6 \% )}$ had no cover, two $(10.53 \%)$ had cover 1 , six (31.58\%) had cover 2 and 10 $(52.63 \%)$ had cover 3 . The difference in the frequency with which incubating birds were killed according to the degree of cover of their nests is highly significant $\left(G_{3} 1 / 426: 31\right.$, $\left.P \unrhd 0: 001\right)$, if we assume that the cover categories of nests in which predation occurred should be similar to those with which nests were found at the population level (Fig. 1).

Males were significantly more vulnerable than females to predators while they were incubating. Five females and 15 males were preyed upon at 19 nests $\left(G_{1} 1 / 4\right.$ 19:1, P \0:001).

\section{Body Condition}

Exposed sites received more solar radiation (ANOVA: $\mathrm{F}_{3 ; 83} 1 / 435: 74, \quad \mathrm{P}$ ! 0:001; Fig. 3) and females nesting in 


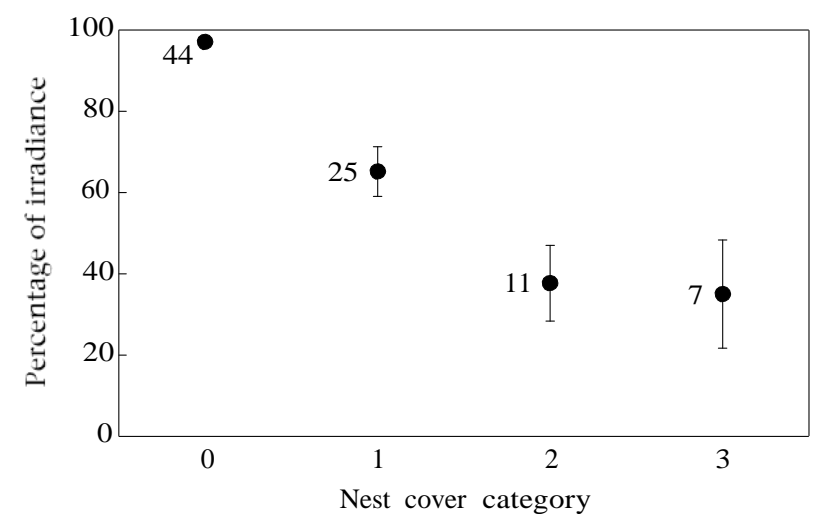

Figure 3. Percentage of solar irradiance (XG1SE) at the centre of Kentish plover nests in relation to that measured in a completely exposed site about $1 \mathrm{~m}$ from the nest, according to degree of nest cover (as defined in Fig. 1). Sample sizes are shown beside the points.

these sites were in better body condition (condition index: $0: 83 G 3: 3, \quad \mathrm{~N} 1 / 461)$ than when they nested in more concealed sites (-0:33G2:5; paired t test: $t_{60} 1 / 42: 24, \quad \mathrm{P} 1 / 4$ $0: 029)$. However, we found no significant difference in the condition of males nesting in exposed sites (0:35G3:1, $\mathrm{N} 1 / 4$ 89) and in more concealed sites (0:23G2:7; paired $\left.\mathrm{t}_{88} 1 / 40: 34, \mathrm{P} 1 / 40: 733\right)$.

\section{DISCUSSION}

\section{Predation Risk and Choice of Nest Sites}

There may be trade-offs between predation risk and choice of thermally favourable sites in birds (Lima \& Dill 1990). Our study shows that Kentish plovers face a tradeoff in the choice of nest sites between predation risk for incubating adults and heat stress. The resolution of this trade-off is state dependent, with birds in low body condition nesting in more risky places, where they are more likely to be killed by predators than plovers nesting in safer, but more thermally stressful sites. Operative temperatures (the sum of air temperature and a temperature increment or decrement that subsumes radiative and convective factors, Bakken 1976) of Kentish plovers were on average 15(C higher in exposed than in covered sites, and plovers in exposed sites showed thermoregulatory behaviour indicative of thermal stress; in contrast, in covered sites the plovers did not show any thermoregulatory behaviour, probably because the thermal range in covered sites was within the thermoneutral zone of the plovers (J. A. Amat \& J. A. Masero, unpublished data). At our study site, nest cover did not affect nesting success, probably because of a high diversity of avian and mammalian predators (Fraga \& Amat 1996). Nevertheless, nests survived longer when they were in sites not accessible to mammals. Although risk of predation on incubating adults may be low, this does not necessarily imply a lack of behavioural sensitivity to predators, and it is precisely this risk that may determine habitat settlement patterns (Lima \& Dill 1990; Lima 1993).

The trade-off between predation risk and choice of thermally favourable sites may mainly concern ground- nesting birds in sites where heat stress during incubation can be a problem. But there may be a similar trade-off for species breeding at colder sites: early detection of potential predators (exposed sites) versus protection against cold winds (covered sites).

Birds choose habitats based on the way in which habitat structure matches their escape tactics (Lima 1993). Gö tmark et al. (1995) suggested that the optimal solution to a trade-off between nest concealment and predation risk for adult passerine birds may be to nest at sites with intermediate cover. This possibility, however, may not apply to Kentish plovers. Shorebirds require a flight path to escape from predators, and vegetation may interfere with their escape by limiting movements (Metcalfe 1984; Walters 1990). Under these circumstances, detecting a predator as soon as possible may be advantageous, and we found that incubating Kentish plovers detected approaching predators sooner in exposed than in covered sites (see also Koivula \& Rönkä 1998), and consequently left exposed nests sooner. It is possible that Kentish plovers in covered nests detected predators as soon as those in exposed nests, but left covered nests later because they were more difficult for the predator to detect (Ydenberg \& Dill 1986). Our observations on the behaviour of incubating plovers do not support this possibility, however, since the plovers left nests almost immediately after they detected a sign of danger, as judged from their alert posture. In fact, the plovers were more frequently killed by predators in covered nests than in exposed ones.

The fact that the plovers reacted differently to different predators, showing the strongest fleeing responses to more dangerous predators, suggests that they can perceive the degree of risk, and this variation in the type of response may be adaptive (Walters 1990).

\section{State-dependent Choice of Sites}

Many of the decisions that animals take are state dependent, and, in general, animals in a poorer state accept more risky situations than those in a better state (Lima 1998). In agreement with this, we found that Kentish plover females in lower body condition nested in covered sites, where predation on incubating adults was more frequent (see also Wiebe \& Martin 1998). It is likely that Kentish plover females in poorer body condition could not incubate in exposed sites because of dehydration problems resulting from direct exposure to the sun (Marder 1983). For breeding birds, physical condition should be regarded as an important component that may affect the coste benefit trade-off of nest sites, as theoretical studies have suggested for feeding sites of foraging individuals (e.g. Lima 1998). However, the choice of nest sites may not only be condition dependent, but is probably also affected by experience with predators, as suggested by the fact that within a nesting season, nest cover did not differ between first and second nests when the first nest was successful, but was greater in second nests when the first nest had been predated (Amat et al. 1999a).

It might be that our index of body condition does not estimate true condition, and that the choice of nest sites is 
affected by other factors. For instance, the more dominant pairs may nest in covered sites, and birds nesting in such sites may reduce their body mass strategically to facilitate escape from predators in such sites. If so, we should expect a greater reduction in body mass in males than in females nesting in covered sites, because as males incubate at night they are more vulnerable to predators than females are (see below). However, our results do not support that possibility. In addition and more importantly, the body condition index that we used is relevant when considering some fitness components of Kentish plovers, as both egg size and within-clutch egg size variation are negatively affected by female body condition (Amat et al. 2001a), and, within clutches, chick survival is affected by egg size (Amat et al. 2001b).

Male Kentish plovers make several scrapes within their territories and females choose one of these as a nest site (Cramp \& Simmons 1983). This may explain why the characteristics of nest sites were related to the body condition of females, and not to that of males. The effect of body condition on the choice of nest sites is probably more critical for females than for males because females perform most diurnal incubation (Nakazawa 1979; Fraga \& Amat 1996). Although incubating Kentish plover females were killed by predators, males suffered much more predation, probably because visibility was reduced at night, when males incubated, as suggested by our experiments on the flushing behaviour of incubating adults. Consequently, by influencing the choice of nest sites, the body condition of females caused variation in the survival of males, and hence could affect life history strategies. Thus, the interval between clutches of polyandrous Kentish plover females at Fuente de Piedra is considerably longer than in other localities, which was assumed to be caused by a limitation of potential mates (Amat et al. 1999b). By affecting sex ratios, predation of incubating adult males could limit the opportunities for polyandrous matings by females.

\section{Acknowledgments}

Consejería de Medio Ambiente (Junta de Andalucía) gave permission to conduct this research at Reserva Natural Laguna de Fuente de Piedra, as well as lodging and many other facilities. Manuel Rendón-Martos, Director of the Nature Reserve, facilitated our work during all phases of the project. In the field, we were assisted by A. Arroyo, J. L. Arroyo, R. Camerana, J. M. Ramírez, J. Rubio, M. Siquier and M. Vázquez. C. M. Herrera loaned the pyranometer to measure radiation at nests. Our thanks also to I. Quintero, U. Safriel, J. Wright and several referees for many helpful comments on the manuscript. Financial support was provided by Plan Andaluz de Investigación (research group RNM 0105) and Dirección General de Investigación Científica y Técnica (grants PB92-0115 and PB95-0110).

\section{References}

Amat, J. A., Fraga, R. M. \& Arroyo, G. M. 1999a. Replacement clutches by Kentish plovers. Condor, 101, 746e751.
Amat, J. A., Fraga, R. M. \& Arroyo, G. M. 1999b. Brood desertion and polygamous breeding in the Kentish plover Charadrius alexandrinus. Ibis, 141 , 596e607.

Amat, J. A., Visser, G. H., Pérez-Hurtado, A. \& Arroyo, G. M. 2000. Brood desertion by female shorebirds: a test of the differential parental capacity hypothesis on Kentish plovers. Proceedings of the Royal Society of London, Series B, 267, 2171e2176.

Amat, J. A., Fraga, R. M. \& Arroyo, G. M. 2001a. Variations in body condition and egg characteristics of female Kentish plovers Charadrius alexandrinus. Ardea, 89, 293e299.

Amat, J. A., Fraga, R. M. \& Arroyo, G. M. 2001b. Intraclutch eggsize variation and offspring survival in the Kentish plover Charadrius alexandrinus. Ibis, 143, 17e23.

Bakken, G. S. 1976. A heat transfer analysis of animals: unifying concepts and the application of metabolism transfer data to field ecology. Journal of Theoretical Biology, 60, 337e384.

Burger, J. 1987. Physical and social determinants of nestsite selection of pipping plover in New Jersey. Condor, 89, 811 e818.

Cairns, W. E. 1982. Biology and behavior of breeding pipping plovers. Wilson Bulletin, 94, 531e545.

Cramp, S. \& Simmons, K. E. L. (Eds) 1983. The Birds of the Western Palearctic. Vol. 3. Oxford: Oxford University Press.

Curio, E. \& Regelmann, K. 1986. Predator harassment implies a real deadly risk: a reply to Hennessy. Ethology, 72,75 e78.

Fraga, R. M. \& Amat, J. A. 1996. Breeding biology of a Kentish plover (Charadrius alexandrinus) population in an inland saline lake. Ardeola, 43, 69e85.

Götmark, F., Blomqvist, D., Johansson, O. C. \& Bergkvist, J. 1995. Nest site selection: a trade-off between concealment and view of the surroundings? Journal of Avian Biology, 26, 305e312.

Grant, G. S. 1982. Avian incubation: egg temperature, nest humidity, and behavioral thermoregulation in a hot environment. Ornithological Monographs, 30, 1 e75.

Klaasen, M., Lindström, ̊̊., Meltofte, H. \& Piersma, T. 2001. Arctic waders are not capital breeders. Nature, 413, 794.

Koivula, K. \& Rönkä, A. 1998. Habitat deterioration and efficiency of antipredator strategy in a meadow-breeding wader, Temminck's stint (Calidris temminckii). Oecologia, 116, 348e355.

Kosztolányi, A. \& Székely, T. 2002. Using a transponder system to monitor incubation routines of snowy plovers. Journal of Field Ornithology, 73, 199e205.

Lauro, B. \& Nol, E. 1995. Patterns of habitat use for pied and sooty oystercatchers nesting at the Furneaux Islands, Australia. Condor, 97, 920e934.

Lima, S. L. 1990. Protective cover and the use of space: different strategies in finches. Oikos, 58, 151 e158.

Lima, S. L. 1992. Strong preference for apparently dangerous habitats? A consequence of differential escape from predators. Oikos, 64, 597e600.

Lima, S. L. 1993. Ecological and evolutionary perspectives on escape from predatory attack: a survey of North American birds. Wilson Bulletin, 105, 1e47.

Lima, S. L. 1998. Stress and decision making under risk of predation: recent developments from behavioral, reproductive, and ecological perspectives. Advances in the Study of Behavior, 27, $215 \mathbf{e} 290$.

Lima, S. L. \& Dill, L. M. 1990. Behavioral decisions made under risk of predation: a review and prospectus. Canadian Journal of Zoology, 68, 619e640.

Maclean, G. L. 1984. Arid-zone adaptations of waders (Aves: Charadrii). South African Journal of Zoology, 19, 78e81.

McNamara, J. M. \& Houston, A. I. 1996. State-dependent life histories. Nature, 380, 215e221. 
Marder, J. 1983. Cutaneous water evaporation: II. Survival of birds under extreme thermal stress. Comparative Biochemistry and Physiology A, 75, 433e439.

Martin, T. E. 1993. Nest predation and nest sites: new perspectives on old patterns. Bioscience, 43, 523e532.

Marzluff, J. M. 1988. Do pinyon jays alter nest placement based on prior experience? Animal Behaviour, 36, 1 e10.

Metcalfe, N. B. 1984. The effects of habitat on the vigilance of shorebirds: is visibility important? Animal Behaviour, 32, 981e985.

Nakazawa, R. 1979. Incubation behaviour of the Kentish plover, Charadrius alexandrinus, with special reference to the share of the sexes and of effect ground surface temperature. Miscellaneous Reports of the Yamashina Institute of Ornithology, 11, 54e63 (In Japanese, English summary).

Page, G. W., Stenzel, L. E. \& Ribic, C. A. 1985. Nest site selection and clutch predation in the snowy plover. Auk, 102, 347e353.

Purdue, J. R. 1976. Thermal environment of the nest and related parental behavior in snowy plovers, Charadrius alexandrinus. Condor, 78, 180e185.

Rendón-Martos, M. \& Johnson, A. R. 1996. Management of nesting sites for greater flamingos. Colonial Waterbirds, 19 (Special Publication 1), 167e183.

Ricklefs, R. E. 1969. An analysis of nesting mortality in birds. Smithsonian Contributions to Zoology, 9, 1 e48.

Sargeant, A. B., Allen, S. H. \& Eberhardt, R. T. 1984. Red fox predation on breeding ducks in midcontinent North America. Wildlife Monographs, 89, 1e41.

Skutch, A. F. 1949. Do tropical birds rear as many young as they can nourish? Ibis, 91 , 430e455.

Thomas, C. S. \& Coulson, J. C. 1988. Reproductive success of kittiwake gulls, Rissa tridactyla. In: Reproductive Success: Studies of Individual Variation in Contrasting Breeding Systems (Ed. by T. H. Clutton-Brock), pp. 251e262. Chicago: Chicago University Press.
Thomas, D. H. \& Maclean, G. L. 1981. Comparison of physiological and behavioural thermoregulation and osmoregulation in two sympatric sandgrouse species (Aves: Pteroclididae). Journal of Arid Environments, 4, 335e348.

Walters, J. R. 1990. Anti-predatory behavior of lapwings: field evidence of discriminative abilities. Wilson Bulletin, 102, 49e70.

Ward, D. 1990. Incubation temperatures of crowned, black-winged, and lesser black-winged plovers. Auk, 107, 10e17.

Warriner, J. S., Warriner, J. C., Page, G. W. \& Stenzel, L. E. 1986. Mating system and reproductive success of a small population of polygamous snowy plovers. Wilson Bulletin, 98, 15 e37.

Weidinger, K. 2002. Interactive effects of concealment, parental behaviour and predators on the survival of open passerine nests. Journal of Animal Ecology, 71, 424e437.

Whittingham, M. J., Percival, S. M. \& Brown, F. 2002. Nest-site selection by golden plover: why do shorebirds avoid nesting on slopes. Journal of Avian Biology, 33, 184e190.

Wiebe, K. L. \& Martin, K. 1998. Costs and benefits of nest cover for ptarmigan: changes within and between years. Animal Behaviour, 56, 1137 e1144.

Wilkinson, L. 1990. SYSTAT: The System for Statistics. Evanston: SYSTAT.

Wolf, B. O. \& Walsberg, G. E. 1996. Thermal effects of radiation and wind on a small bird and implications for microsite selection. Ecology, 77, 2228e2236.

Ydenberg, R. C. \& Dill, L. M. 1986. The economics of fleeing from predators. Advances in the Study of Behavior, 16, 229e249.

Zar, J. H. 1984. Biostatistical Analysis. 2nd edn. London: PrenticeHall.

Zharikov, Y. V. \& Bondrup-Nielsen, S. 1996. Behavioural responses of pipping plovers Charadrius melodus to potential predators and experiments with artificial nests. Russian Journal of Ornithology, $5,47 \mathbf{e} 52$. 